\title{
KAJIAN KEBIJAKAN PEMERINTAH INDONESIA DALAM PERDAGANGAN CPO INDONESIA MENGGUNAKAN PENDEKATAN ANALISIS INTEGRASI PASAR
}

\section{(STUDY ON INDONESIAN GOVERNMENT POLICY ON CPO TRADE USING MARKET INTEGRATION APPROACH)}

\author{
Dian Hafizah \\ Jurusan Sosial Pertanian Fakultas Pertanian \\ Universitas Andalas \\ sweet_dianhafizah@yahoo.co.id
}

\begin{abstract}
ABSTRAK
Crude Palm Oil (CPO) is one of important commodity for Indonesia. Indonesia is the biggest producers of CPO in the world, and the second exporter after Malaysia. Despite the fact that Indonesia and Malaysia are mayor CPO exporters, CPO traders determine CPO price in spot market. As a result, Indonesian and Malaysian producers often face price volatilites. Indonesian traders do not have bargaining power in the price determination. On other hands, domestik demands for CPO grow up. For that reason, The Indonesian goverment must take a policy to guarantee the fulfilment of CPO needs. The objective of research are (1) to describe the Indonesian policy in CPO trade that integrated with World market in Rotterdam and Malaysian Market and (2) to formulate the policy implication of CPO price formation in Indonesia. The research showed that Indonesia act as price taker, this is because Indonesian goverment has no bargaining power to determine price in domestic - and international market. To solving the problem is important for goverment to develop CPO's future market and create product diversification for CPO.
\end{abstract}

Keywords: Crude Palm Oil, Goverment Policy, Price, Integration market

\section{PENDAHULUAN}

CPO adalah komoditi penting Indonesia. CPO adalah andalan ekspor Indonesia dimana Indonesia adalah produsen terbesar CPO dunia dan pangsa pasar CPO Indonesia adalah nomor 2 terbesar setelah Malaysia yaitu sebesar 32.64 persen. Sebagai salah satu penghasil CPO terbesar di dunia maka Indonesia seharusnya memiliki kemampuan untuk mengontrol pergerakan $\mathrm{CPO}$ baik dalam jumlah ataupun harganya. Pada kenyataannya Indonesia belum mampu mengatasi flutuasi harga CPO dari waktu ke waktu. Fluktuasi harga di pasar dunia maupun lokal akan menimbulkan resiko yaitu bila dilaksanakan langsung dengan penyerahan fisik (spot) yakni resiko kerusakan fisik dan 
penurunan nilai. Resiko fisik meliputi penurunan kualitas komoditi CPO karena adanya proses penyimpanan untuk mengatasi fluktuasi harga atau karena penundaan penjualan untuk menunggu harga yang lebih baik. Penurunan nilai contohnya adalah akibat harga yang tiba-tiba jatuh sehingga merugikan pihak produsen.

Selain itu, CPO juga banyak digunakan untuk kepentingan pemenuhan kebutuhan domestik. CPO -merupakan bahan baku utama dalam pembuatan minyak goreng yang merupakan salah satu dari kebutuhan pokok masyarakat Indonesia. Konsumsi minyak goreng untuk Indonesia sendiri terus mengalami peningkatan, konsumsi per kapita sebesar16.5 kg per orang dan khusus untuk minyak goreng sawit sebesar $12.7 \mathrm{~kg}$ per orang. Tahun 2005 konsumsi minyak goreng Indonesia 6 juta ton dan 83.3 persen dari jumlah tersebut untuk penggunaan minyak goreng sawit. Tahun 2008 total konsumsi CPO untuk keperluan pembuatan minyak goreng dalam negeri setara dengan 24.9 persen dari produksi CPO nasional. Untuk dapat mengakomodir seluruh kepentingan dari berbagai elemen dimana volume perdagangan dapat ditingkatkan namun juga tetap menjamin ketersediaan $\mathrm{CPO}$ dalam negeri maka pemerintah mutlak perlu menetapkan kebijakan kebijakan terkait dengan hal tersebut.

Penelitian ini dimaksudkan untuk mendeskripsikan kondisi perdagangan CPO baik domestik maupun dunia serta kebijakan yang telah diambil pemerintah Indonesia yang terkait dengan perdagangan CPO dan Bagaimana implikasi kebijakan yang seharusnya diambil oleh pemerintah dengan melihat posisi Indonesia dalam perdagangan $\mathrm{CPO}$ dunia yang saling terintegrasi dengan produsen lainnya yaitu Malaysia dan Pasar CPO dunia yang bertempat di Rotterdam Belanda.

\section{METODE PENELITIAN}

Metode yang digunakan dalam penelitian ini adalah metode deskriptif. Menurut Nazir (1999) metode deskriptif adalah merupakan suatu metode dalam meneliti suatu objek, suatu set kondisi, suatu sistem pemikiran ataupun suatu kelas peristiwa dengan tujuan untuk membuat deskripsi, gambaran secara sistematis, factual dan akurat mengenai fakta fakta, sifat-sifat, serta hubungan antar fenomena yang diselidiki. Dengan menggunakan metode ini memungkinkan untuk mendapatkan informasi yang lebih detail mengenai keadaan selama ini.

Untuk menjawab tujuan kedua yaitu merumuskan implikasi implikasi yang terjadi dalam pembentukan harga $\mathrm{CPO}$ yang terintegrasi dengan pasar CPO dunia terhadap kebijakan perdagangan CPO di Indonesia maka akan digunakan analisis kualitatif. Data yang dipergunakan adalah data sekunder. Pengumpulan data dalam penelitian ini dilakukan dengan menggunakan metode dokumentasi dimana data dikumpulkan melalui Badan Pengawas Perdagangan Berjangka Komoditi (Bappebti) dan dari dinas dan instansi yang 
terkait lainnya seperti Departemen Perdagangan, Departemen Perindustrian dan Badan Pusat Statistik Indonesia.

\section{HASIL DAN PEMBAHASAN}

\section{Sejarah Pengembangan Kelapa Sawit di Indonesia}

Kelapa Sawit (Elais guineensis Jacq) pertama kali didatangkan dari daerah pesisir tropis Afrika Barat. Indonesia dan Malaysia adalah daerah yang paling sesuai sebagai daerah pengembangan kelapa sawit. Sekarang ini Malaysia dan Indonesia merupakan dua negara utama produsen minyak kelapa sawit yang menguasai sekitar 85 persen pangsa pasar dunia (Pahan, 2008).

Pengembangan areal dan produksi kelapa sawit di Indonesia terbagi dalam tiga kelompok besar yaitu melalui perkebunan rakyat, perkebunan besar negara dan perkebunan besar swasta. Ciri utama perkebunan rakyat adalah areal yang menyebar, luasan pemilikan lahan/kebun yang relatif tidak merata, tingkat penerapan tehnologi yang masih rendah dan manajemen yang belum rapi. Secara nasional laju pertumbuhan areal perkebunan rakyat mencapai 6,78 persen (Agustian dan Hadi, 2002).

Luas area pertanaman kelapa sawit di Indonesia terus mengalami peningkatan sejak tahun 1999 hingga tahun 2006. Peningkatan tertinggi terjadi dalam kurun waktu 2000-2001 yaitu seluas 555358 hektar (13,36 persen) dan kurun waktu 2005-2006 yaitu seluas 621109 hektar (11,39 persen). Hasil perkiraan sementara untuk tahun 2007 hingga tahun 2009, luas area pertanaman kelapa sawit di Indonesia masih akan terus mengalami peningkatan seluas 350 135 hektar pada tahun 2007 dan 350135 hektar pada tahun 2009. Sementara itu produktivitas perkebunan negara, rakyat dan swasta dalam 5 tahun terakhir masing-masing meningkat dari 4,79 dan 3,18 serta 3,21 ton CPO per hektar per tahun menjadi 5,23 dan 3,69 serta 3,28 ton CPO per hektar per tahun.

\section{Permintaan Crude Palm Oil}

Menurut Pahan (2008) konsumsi CPO di dunia bersaing dengan empat belas jenis minyak nabati yang terdapat didunia karena masing-masingnya saling menggantikan (bersubtitusi). Walaupun begitu dari waktu ke waktu konsumsi dunia terhadap produk $\mathrm{CPO}$ makin meningkat dimana menurut Oil World pada tahun 2003 konsumsi dunia mencapai 123,95 juta ton dan pada tahun 2007 mencapai 153,84 juta ton dengan rata-rata pertumbuhan 4,78 persen per tahunnya.

Khusus di Indonesia peningkatan konsumsi didorong oleh permintaan turunan dari permintaan minyak goreng yang merupakan permintaan utama masyarakat terutama untuk konsumsi rumah tangga dan kebutuhan industri hilir. Menurut CIC (2004) dalam Rifin (2009) untuk memenuhi konsumsi akan minyak goreng pada tahun 2008 maka Indonesia membutuhkan 4,9 juta ton $\mathrm{CPO}$. Penggunaan untuk minyak goreng ini merupakan porsi yang terbesar yakninya sebesar 76 persen dari penggunaan minyak kelapa sawit domestik.

Dian Hafizah. Kajian Kebijakan Pemerintah dalam Perdagangan CPO... | 156 
Sisanya adalah untuk pembuatan margarin (6 persen), sabun ( 7 persen) dan untuk keperluan di bidang kimia (11 persen). Adapun persentase penggunaan minyak kelapa sawit untuk keperluan domestik untuk memenuhi seluruh kebutuhan tersebut adalah sebesar 34,42 persen dari total produksi Indonesia.

Menurut Pahan (2008) faktor-faktor yang mempengaruhi volume permintaan minyak kelapa sawit di pasar domestik dan dunia adalah: (1) pertambahan penduduk dan pertumbuhan GDP, (2) kepentingan politik masing-masing negara, (3) letak geografis suatu negara dan biaya transportasi ke negara tersebut, (4) akses informasi, dan (5) tingkat subtitusi produk.

\section{Produksi Crude Palm Oil}

Penghasil $\mathrm{CPO}$ terbesar dunia adalah Indonesia dan Malaysia dimana pada tahun 2006 produksi Indonesia adalah 16000 ribu ton atau jika dihitung share-nya adalah 43.21 persen dan pada tahun 2007 produksinya meningkat menjadi 16700 ribu ton atau 43.80 persen dari total produksi dunia. Sedangkan produksi CPO Malaysia adalah sebesar 15881 ribu ton atau share-nya adalah 43,91 persen pada tahun 2006 dan pada tahun 2007 produksinya menjadi 15823 ribu ton.

Indonesia memiliki peluang pertumbuhan produksi yang relatif lebih tinggi dibandingkan Malaysia mengingat ketersediaan lahan dan tehnologi produksi yang belum dimanfaatkan secara optimal. Hal yang patut diwaspadai adalah berkembangnya industri sawit di negara-negara lain yang ditunjukkan dengan melonjaknya pertumbuhan produksi CPO yang mencapai 22,02 persen jauh diatas Indonesia dan Malaysia (Sugema et al. 2007). Pernyataan ini terbukti dimana pada tahun 2008 produksi Indonesia lebih tinggi dibandingkan Malaysia dimana selisihnya mencapai hampir seribu juta ton padahal pada tahun 2005 produksi Malaysia masih lebih unggul.

Menurut data yang dikumpulkan oleh Biro Pusat Statistik (BPS) pada tahun 2006 produksi kelapa sawit yang dihasilkan baik oleh perkebunan rakyat, perkebunan besar negara maupun perkebunan besar swasta dari tahun ke tahun menunjukkan peningkatan yang nyata sejak tahun tahun 1999 hingga 2006. Hal ini disebabkan juga antara lain karena adanya perluasan lahan yang dilakukan. Pada tahun 2001 produksi Indonesia sebanyak 1395964 ton (19,94 persen), tahun 2002 sebanyak 1225873 ton (14,60 persen) dan tahun 2006 produksi sudah meningkat drastis sebanyak 1529192 ton (12,89 persen). Begitupun dengan perkebunan besar negara dimana jika pada tahun 2001 produksinya hanya 1,52 juta ton maka pada tahun 2005 hasilnya meningkat menjadi 16,48 juta ton dan keberhasilan ini juga diikuti oleh perkebunan besar swasta dimana produksi yang hanya 4,08 juta ton di tahun 2001 dapat ditingkatkan menjadi 54 juta ton pada tahun 2005 (Tabel 1). 
Tabel 1. Perkembangan Produksi Crude Palm Oil Indonesia dan Dunia Periode Tahun 2005-2007 dan Proyeksi 2008 (juta ton)

\begin{tabular}{lrrrr}
\hline \multirow{2}{*}{ Negara } & \multicolumn{3}{c}{ Produksi } \\
\cline { 2 - 5 } & 2008 & 2007 & 2006 & 2005 \\
\hline Indonesia & 18800 & 16700 & 16000 & 10436 \\
Malaysia & 17300 & 15823 & 15881 & 13439 \\
Thailand & 1170 & 1020 & 860 & 700 \\
Nigeria & 860 & 835 & 815 & 800 \\
Pantai Gading & 330 & 320 & 330 & 320 \\
Columbia & 780 & 735 & 713 & 673 \\
P.N Guinea & 430 & 405 & 365 & 310 \\
Ecuador & 415 & 396 & 352 & 319 \\
Costa Rica & 235 & 215 & 198 & 210 \\
Honduras & 228 & 210 & 195 & 180 \\
Brazil & 220 & 190 & 170 & 160 \\
Mexico & 62 & 57 & 50 & 43 \\
Other & 1288 & 1222 & 1161 & 1083 \\
\hline Total Dunia & 42218 & 38129 & 37140 & 33858 \\
\hline
\end{tabular}

Sumber: Oil World, 2008

Berdasarkan hasil perkiraan sementara untuk tahun 2007 hingga tahun 2009, tingkat produksi kelapa sawit di Indonesia masih akan terus mengalami peningkatan. Tahun 2007 diperkirakan akan terjadi peningkatan produksi sebanyak 761176 ton (5.68 persen), sementara pada tahun 2008 diperkirakan akan terjadi peningkatan produksi sebanyak 968661 ton (6,84 persen). Tahun 2009 diperkirakan akan terjadi peningkatan produksi sebanyak 970856 ton atau bila dihitung kenaikannya sebesar 6,42 persen (Sugema et al. 2007).

\section{Kondisi Pasar Crude Palm Oil Indonesia}

Sejalan dengan perkembangan produksi dimana yang paling banyak memproduksi kelapa sawit adalah Indonesia dan Malaysia maka negara pengekspor terbesar di dunia juga didominasi oleh kedua negara ini. Berdasarkan Tabel 1 produksi Indonesia lebih besar dibandingkan dengan produksi Malaysia, namun Indonesia menempati urutan kedua setelah Malaysia dalam hal jumlah ekspor dan penguasaan pangsa pasar dunia.

Produksi CPO Indonesia selain untuk tujuan ekspor juga ditujukan untuk memenuhi kebutuhan dalam negeri. CPO sendiri adalah bahan baku utama dalam pembuatan minyak goreng yang merupakan salah satu kebutuhan pokok masyarakat. Berdasarkan hal itu ketersediaan CPO harus dapat dipenuhi oleh pemerintah dengan harga yang terjangkau.

Ekspor Indonesia pada tahun 2006 adalah sebesar 5199 juta ton dengan nilai adalah 1999 juta USD, hal ini mengalami peningkatan dibandingkan pada tahun 2000 yang hanya 1818 juta ton dengan nilai 476 juta USD. Pada tahun 
2007 juga terjadi peningkatan jumlah ekspor dengan laju 5.22 persen pertahun. Tetapi meskipun dalam beberapa tahun ini ekspor CPO Indonesia meningkat, Malaysia tetap lebih unggul dibandingkan Indonesia (Agustian dan Hadi, 2002).

Khusus untuk Negara Indonesia maka dapat dilihat bahwa CPO adalah salah satu dari 10 besar komoditi ekspor andalan Indonesia dalam mendapatkan devisa. Secara umum ekspor Indonesia semenjak tahun 2000 selalu menunjukkan peningkatan.

Tercatat ekspor Indonesia pada tahun 2000 adalah sebesar 1818 ribu ton dan apabila dihitung nilainya maka didapatkan nilai USD 476 juta. Nilai ekspor CPO pada tahun 2006 adalah sebesar US\$ 1993666661 dengan share-nya adalah 6,9 persen jumlah ini mengalami peningkatan dibandingkan dengan share pada tahun 2003 yang hanya 4 persen.

Volume perdagangan pada tahun 2006 adalah sebesar 5199 ribu ton. Perbandingan dengan tahun sebelumnya, terjadi peningkatan sebesar kira-kira 900 ribu ton dimana volume ekspor pada tahun 2005 hanya 4566 ribu ton. Nilainya setara dengan USD 1444 juta. Negara tujuan ekspor CPO Indonesia adalah India, Belanda dan China. Khusus untuk ekspor Indonesia ke negara tujuan seperti yang telah disebutkan sebelumnya, masing-masing negara ratarata permintaannya meningkat dari tahun ke tahun. Pada tahun 2007 sekitar 73 persen minyak kelapa sawit Indonesia diekspor sisanya digunakan untuk kebutuhan domestik. Sekitar 70 persen ekspor CPO Indonesia ditujukan ke negara-negara Asia, 21 persen ke Eropa dan sisanya ke bahagian dunia lain Rifin, 2009).

Negara India merupakan negara tujuan ekspor terbesar CPO bagi Indonesia. Tercatat pada tahun 1997 ekspor Indonesia adalah sebesar 469,56 ribu ton dan setelah 5 tahun kemudian ekspor Indonesia meningkat hampir dua kali lipat menjadi 877,81 ribu ton dan pada tahun 2007 ekspor CPO Indonesia ke India mencapai 3311,5 ribu ton. Menurut Rifin (2009) pada tahun 2006 Indonesia telah mengekspor CPO dan turunannya ke India hingga mencapai 57 persen dari kebutuhan impor India dimana 91 persen adalah dalam bentuk CPO.

Negara tujuan ekspor Indonesia yang kedua terbanyak adalah untuk China dimana ekspor Indonesia pada tahun 2003 sebesar 1172.0 ribu ton, dan selama lima tahun kemudian yaitu pada tahun 2007 ekspor Indonesia ke China terus meningkat menjadi sebesar 2346,1 ribu ton. Adapun 91 persen impor China adalah dalam bentuk turunan CPO dimana konstribusi ekspor Indonesia adalah sebesar 34 persen. Malaysia adalah termasuk negara pengekspor CPO, namun negara ini juga mengimpor CPO dari Indonesia (Rifin, 2009).

\section{Malaysia}

Pada tahun 1969 pangsa ekspor Malaysia mencapai 43.48 persen dari ekspor minyak sawit dunia sedangkan Indonesia hanya sekitar 20,49 persen dan pada tahun 1999 pangsa ekspor Malaysia sebesar 65 persen dan Indonesia sebesar 23 persen. Begitupun pada tahun 2002 ekspor Malaysia sebesar 57,28 
persen dan Indonesia sebesar 32,64 persen. Pada tahun 2008 diperkirakan nilai ekspor Malaysia dan Indonesia akan terus meningkat dimana Malaysia akan terus memimpin dengan jumlah ekspor 5,61 juta ton atau share-nya 33,32 persen untuk Indonesia dan 8,78 juta ton atau share-nya 56,90 persen untuk Malaysia. Tingginya perbedaan pangsa ekspor ini terjadi karena sebagian besar dari produksi CPO Indonesia dialokasikan untuk konsumsi dalam negeri (Agustian dan Hadi, 2002).

Negara-negara yang menjadi pangsa pasar Malaysia sebagai negara pesaing Indonesia antara lain adalah pasar China, India, EU, Pakistan dan Jepang sebesar 0,4 juta ton. Pada tahun 2007 negara pengimpor terbesar CPO yang berasal dari Malaysia adalah China dimana jumlahnya adalah sebesar 3841,6 ribu ton atau jika dipersentasekan adalah sebesar 27 persen dari keseluruhan ekspor Malaysia. Posisi kedua diikuti oleh negara Belanda dimana pada tahun 2007 ekspor Malaysia ke Belanda adalah sebesar 1 466,3 ribu ton atau bila dihitung persentasenya adalah sebesar 10 persen dari total keseluruhan ekspor Malaysia. Seperti yang sudah dijelaskan selain mengekspor CPO Malaysia juga juga mengimpor dari beberapa negara untuk diolah lebih lanjut. Menurut data yang diperoleh dari oil world ada tahun 2007 Malaysia mengimpor CPO dari Indonesia, Thailand (39,3 ribu ton) dan Papua New Guinea (6,1 ribu ton).

\section{Rotterdam}

Salah satu negara tujuan ekspor Indonesia dan Malaysia adalah untuk Rotterdam (Belanda) dimana impor CPO dari kedua negara terus meningkat dari tahun ke tahunnya. Pada tahun 2006 dari seluruh jumlah minyak dan lemak yang diimpor oleh Belanda 79 persennya adalah dalam bentuk CPO yang dipenuhi dari ekspor yang dilakukan oleh Indonesia dan Malaysia. Pada tahun 2007 share dari kedua negara masing-masingnya adalah 61,43 persen untuk Malaysia dan 32,54 persen untuk Indonesia. Untuk lebih jelasnya dapat dilihat pada Tabel 2.

Tabel 2. Jumlah Impor Crude Palm Oil Rotterdam Berdasarkan Negara Asal(ribu Ton)

\begin{tabular}{lrrrrrrrrrrr}
\hline \multirow{2}{*}{$\begin{array}{c}\text { Negara } \\
\text { Asal }\end{array}$} & \multicolumn{10}{c}{ Tahun } \\
\cline { 2 - 12 } & \multicolumn{2}{c}{ Jumlah } & \multicolumn{1}{c}{$\%$} & \multicolumn{1}{c}{2006} & \multicolumn{1}{c}{2005} & \multicolumn{2}{c}{2004} & \multicolumn{2}{c}{2003} \\
\hline Malaysia & 1092,5 & 61,43 & 960,8 & 56,85 & 791,3 & 52,39 & 690,7 & 53,96 & 638,7 & 55,67 \\
Indonesia & 578,7 & 32,54 & 677,6 & 40,09 & 613,7 & 40,63 & 530,7 & 41,46 & 457,9 & 39,91 \\
Lainnya & 107 & 6,02 & 51,6 & 3,05 & 105,5 & 6,98 & 58,6 & 4,57 & 50,6 & 4,41 \\
\hline Total & 1778,2 & 100 & 1690,0 & 100 & 1510,5 & 100 & 1280,0 & 100 & 1147,2 & 100 \\
\hline
\end{tabular}

Sumber: Oil World, 2008

Tidak seperti negara-negara lain yang mengimpor untuk memenuhi kebutuhan dalam negerinya Belanda menggunakan CPO dan turunannya yang

Dian Hafizah. Kajian Kebijakan Pemerintah dalam Perdagangan CPO... | 160 
diimpor dari negara lain untuk diekspor kembali. Persentase untuk dijual kembali adalah sebanyak 92 persen dengan tujuan ekspor utama ke negaranegara Uni Eropa lainnya seperti Jerman, Belgia dan Inggris. Belanda tidak melakukan pengolahan apapun dimana fungsi Belanda adalah murni sebagai perantara antara negara produsen dengan negara konsumen.

\section{Kebijakan Perdagangan Crude Palm Oil}

Tujuan dari pemerintah Indonesia dalam melakukan kebijakan adalah karena minyak kelapa sawit adalah produk penting pada perekonomian Indonesia. Salah satu dari konstribusinya dalam perekonomian negara sebagai penyumbang devisa terbesar. Selain itu CPO merupakan bahan baku utama dalam pembuatan minyak goreng. Konsumsi minyak goreng untuk Indonesia sendiri terus mengalami peningkatan, dimana konsumsi perkapita adalah 16,5 $\mathrm{kg}$ per orang dan khusus untuk minyak goreng sawit sebesar $12,7 \mathrm{~kg}$ per orang. Pada tahun 2005 konsumsi minyak goreng Indonesia adalah 6 juta ton dan 83,3 persen dari jumlah tersebut adalah untuk penggunaan minyak goreng sawit. Penggunaan CPO untuk minyak goreng adalah sebanyak 76 persen (Rifin, 2007).

Minyak goreng di Indonesia adalah termasuk dalam sembilan kebutuhan bahan pokok masyarakat yang harus tercukupi ketersediaannya. Sebagai bahan pangan pokok ketersediaan minyak goreng dengan harga yang terjangkau bukan saja penting bagi kestabilan perekonomian namun juga dapat mengganggu keamanan sosial dan akan meresahkan masyarakat bila tidak tersedia. Mengingat pentingnya keberadaan minyak goreng di Indonesia maka CPO sebagai bahan baku pembuat utamanya juga harus dijamin ketersediaannya oleh pemerintah Indonesia.

Menurut Pahan (2008) adanya kebijakan dalam perdagangan CPO misalnya dalam bentuk hambatan tarif yang diwujudkan dalam bentuk pajak ekspor yang diterapkan oleh negara pengekspor, maupun bea masuk yang diberlakukan oleh negara pengimpor akan mempengaruhi keseimbangan baru dalam permintaan dan penawaran di pasar. Salah satu bentuk penerapan hambatan baik dalam bentuk tarif ataupun dalam bentuk nontarif yang dilakukan beberapa negara terhadap produk CPO antara lain adalah: (1) negaranegara Eropa memberikan subsidi bagi produk minyak canola yang merupakan komoditi saingan CPO dalam negeri dan kampanye negatif terhadap minyak yang berasal dari kelapa sawit berupa pengrusakan hutan tropis, kepunahan orang utan dan lain lain, (2) India dan China menetapkan bea masuk yang tinggi untuk melindungi produk nabati dalam negeri, dan (3) adanya kampanye anti minyak kelapa sawit yang dilakukan oleh American Soybean Association (ASA) yang menjurus pada tindakan diskriminatif dan menyesatkan.

Terdapat beberapa kebijakan di Indonesia yang diterapkan terkait komoditas kelapa sawit khususnya CPO. Sebagai salah satu unggulan ekspor dari pemerintah dan sekaligus merupakan bahan baku untuk memenuhi kebutuhan pokok dari masyarakat yang pasokannya tidak boleh terputus atau akan dapat merusak kestabilan ekonomi masyarakat, pemerintah ikut mengatur 
jumlah dan harga CPO baik untuk kebutuhan domestik maupun untuk tujuan ekspor. Berdasarkan hal tersebut pemerintah harus menerapkan suatu kebijakan yang tepat sehingga $\mathrm{CPO}$ sebagai produk ekspor unggulan Indonesia dapat bersaing di pasar internasional. Sehingga menyumbang devisa namun juga tidak mengabaikan ketersediannya untuk memenuhi kebutuhan domestik

Tahun 1978 pemerintah mengambil kebijakan dengan mengatur pemasaran minyak di dalam negeri terutama pengaturan kerja dan pengaturan alokasi penggunaan produksi. Tujuannya adalah untuk menjaga stabilitas harga minyak goreng pada tingkat konsumen, mendorong ekspor produksi nabati yang telah diproses. Pengaturan alokasi produksi dalam negeri diatur melalui Surat Keputusan Bersama (SKB) Tiga Menteri No. 275/KPB/XII/78 tanggal 16 Desember 1978. Berdasarkan SKB tersebut ditetapkan bahwa: (1) harga minyak kelapa sawit untuk pembuatan minyak goreng ditetapkan di Belawan, (2) harga minyak kelapa sawit untuk operasi pasar berdasarkan minyak goreng dikurangi dengan biaya operasional, dan (3) harga CPO untuk industri hilir sama dengan harga ekspor FOB (Freight On Board) Belawan. Beberapa ketentuan pokok dalam peraturan tersebut adalah: (1) semua produsen CPO diwajibkan menyediakan minyak sawit untuk kebutuhan dalam negeri, (2) jumlah yang harus disediakan oleh produsen ditetapkan oleh menteri pertanian, (3) harga CPO untuk bahan baku industri dalam negeri ditetapkan oleh menteri perdagangan dan koperasi dengan memperhatikan pendapat menteri pertanian dan menteri perindustrian, harga $\mathrm{CPO}$ dalam negeri ditetapkan oleh menteri perdagangan dan koperasi setiap 3 bulan sekali berdasarkan FOB Belawan, dan (4) penyediaan CPO di dalam negeri yang tidak ditebus dapat diekspor oleh produsen.

Tahun 1983 melalui SK Dirjen Perdagangan Dalam Negeri No. 22/DAGRI $\mathrm{KP} / \mathrm{T} / 83$ pemerintah mengatur alokasi $\mathrm{CPO}$. Seluruh alokasi $\mathrm{CPO}$ yang disediakan untuk kebutuhan dalam negeri tidak boleh diperjualbelikan dimana jumlah efektif yang harus didistribusikan ke dalam negeri penetapan harganya diatur melalui SKB menteri perdagangan dan koperasi, menteri pertanian dan menteri perindustrian.

Tahun 1991 SKB tiga menteri dihapus dimana dengan penghapusan itu maka melonggarkan semua ketentuan tataniaga untuk memacu ekspor dan mendorong investasi namun akibatnya minyak goreng menjadi langka di domestik sehingga tahun 1994 pemerintah mengeluarkan Instrumen Pajak Ekspor (PE) melalui SK menteri keuangan No. 439/KMK.017/1994 tanggal 31 Agustus 1994, dimana terhitung mulai tanggal 1 September 1994 pemerintah akan menetapkan PE jika harga minyak goreng dalam negeri diatas Rp 1 $250 / \mathrm{kg}$. Adapun tujuan lainnya dari dilakukannya kebijakan ini adalah untuk meningkatkan devisa negara melalui instrumen pajak penghasilan dan pertambahan nilai serta restribusi.

Besarnya PE ditetapkan berdasarkan keputusan dari menteri keuangan sedangkan nilai Harga Patokan Ekspor (HPE) ditetapkan oleh mentri perdagangan dimana Pungutan Ekspor dihitung dari hasil perkalian antara tarif pajak ekspor, jumlah ekspor, HPE dan nilai tukar rupiah terhadap dolar. Harga Freight on Board (FOB) ditentukan oleh Menteri keuangan setiap bulannya 
berdasarkan harga dunia dua minggu sebelumnya, sedangkan harga dasar adalah harga ekspor maksimum yang bebas pungutan ekspor. Adapun HPE ditetapkan oleh menteri perindustrian dan perdagangan setiap bulannya tergantung dari harga intenasional CPO dan turunannya (Rifin, 2009). Perkembangan perubahan PE dan HPE untuk tahun 2007 hingga 2008 dapat dilihat pada Tabel 3.

Seiring dengan peningkatan harga minyak kelapa sawit dunia maka dikeluarkan Peraturan menteri keuangan no 92/PMK.011/2007 yang berlaku mulai September 2007 dan direvisi kembali pada tahun 2008 melalui peraturan menteri keuangan no 09/PMK.011/2008 dimana isinya adalah penetapan tarif pungutan ekspor untuk minyak kelapa sawit dan turunannya ditentukan berdasarkan harga referensi pada harga internasional yang berlaku. Akibatnya apabila harga internasional naik maka tarif pungutan ekspornya juga akan naik. Tujuan dibuatnya kebijakan ini adalah untuk menjamin keberlangsungan keutuhan bahan baku domestik dan menjaga stabilitas harga minyak goreng.

Tabel 3. Perkembangan Perubahan Pajak Ekspor dan Harga Patokan Ekspor Tahun 2007- 2008

\begin{tabular}{|c|c|c|c|c|c|c|c|c|c|c|c|}
\hline \multirow{3}{*}{ Komoditi } & \multicolumn{11}{|c|}{ Periode tahun 2007} \\
\hline & \multirow{2}{*}{ PE (\%) } & \multicolumn{6}{|c|}{ HPE(USD)/MT } & \multirow{2}{*}{$\begin{array}{l}\mathrm{PE} \\
(\%)\end{array}$} & \multicolumn{3}{|c|}{ HPE (USD)/MT } \\
\hline & & Jan & $\mathrm{Feb}$ & Mar & Apr & Mei & Jun & & Juli & Agst & \\
\hline $\mathrm{CPO}$ & 1,5 & 458 & 487 & 490 & 525 & 558 & 622 & 6,5 & 676 & 728 & \\
\hline Crude Olein & 0,3 & 477 & 541 & 553 & 564 & 571 & 669 & 6,5 & 740 & 767 & \\
\hline \multirow[t]{3}{*}{ RDB Olein } & 0,3 & 488 & 552 & 570 & 574 & 585 & 676 & 6,5 & 746 & 801 & \\
\hline & & & & & \multicolumn{7}{|c|}{ Periode tahun 2008} \\
\hline & & sep & okt & nov & des & PE (\%) & Feb $(10 \%)$ & $\begin{array}{l}\text { April } \\
(20 \%)\end{array}$ & $\begin{array}{c}\text { Juni } \\
(15 \%)\end{array}$ & $\begin{array}{c}\text { Juli } \\
(20 \%)\end{array}$ & $\begin{array}{l}\text { Agust } \\
(15 \%)\end{array}$ \\
\hline $\mathrm{CPO}$ & 7,5 & 786 & 760 & 784 & 862 & \multirow{3}{*}{ 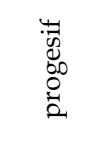 } & 944 & 1196 & 1196 & 1144 & 1144 \\
\hline Crude Oil & 7,5 & 786 & 763 & 814 & 892 & & 983 & 1288 & 1288 & 1224 & 1224 \\
\hline RDB Olein & 7,5 & 779 & 773 & 824 & 902 & & 996 & 1303 & 1303 & 1261 & 1261 \\
\hline
\end{tabular}

Sumber: Departemen Perdagangan, 2008

Pada tahun 2008 jumlah ekspor CPO Indonesia melambat akibat adanya kebijakan Indonesia terkait dengan pajak yang meningkat naik pada April 2008 melalui Peraturan Menteri Keuangan No. 09/PMK.011/2008 terkait dengan peningkatan tingkat pajak berdasarkan harga referensi pada harga internasional yang berlaku dimana penetapannya ditinjau setiap bulannya. Akibatnya apabila harga internasional naik maka tarif pungutan ekspornya juga akan naik.

Beberapa kebijakan yang diterapkan pemerintah terkait dengan CPO adalah dengan menerapkan pajak ekspor CPO melalui Peraturan Menteri Keuangan No. 118/PMK.011/2007 yang berlaku mulai September 2007 dan kemudian dibuat kebijakan pada tahun 2008 melalui Peraturan Menteri Keuangan No. 14/PMK.011/2008 15/PMK.011/2008 tentang pajak nilai tambah 
dari minyak goreng. Peraturan ini menyebutkan bahwa pemerintah akan membayar nilai tambah bagi minyak goreng yang dijual di dalam negeri baik yang telah dikemas maupun yang belum. Tujuan dari kebijakan ini adalah untuk melindungi konsumen agar dapat membeli minyak goreng dengan harga yang murah namun produsen tidak dirugikan.

Penetapan kebijakan yang telah dilakukan oleh pemerintah bertujuan agar dapat menjaga ketersediaan $\mathrm{CPO}$ di dalam negeri untuk memenuhi kebutuhan domestik dengan harga yang terjangkau. Pada saat harga internasional (Rotterdam) CPO bulan Januari 2008 USD 1055.92 per ton naik senilai USD 1160, 1233, 1169, 1203, 1204 berturut-turut hingga Juni 2008 harga CPO di domestik tetap stabil berturut-turut dari januari 2008 hingga Juni 2008 dikisaran Rp 9233, Rp 9965, Rp 9707, Rp 9332, Rp 9967 dan Rp 9544 per kilogram. Artinya penerapan pajak ekspor oleh pemerintah efektif dalam menstabilkan harga CPO di domestik.

Setelah kenaikan harga $\mathrm{CPO}$ yang tajam ternyata diikuti dengan penurunan drastis dari harga CPO internasional. Mulai dari bulan Juni 2008 yang merupakan harga tertinggi CPO selama periode penelitian yaitu USD 1204 per ton harga kemudian turun hingga USD 624 menjadi USD 580 per ton. Artinya dalam kurun waktu 6 bulan harga turun menjadi setengahnya dari harga enam bulan sebelumnya. Turunnya harga komoditi khususnya CPO antara lain disebabkan karena turunnya harga minyak bumi dunia dimana hal ini sesuai dengan yang dikatakan dalam penelitian yang dilakukan oleh Amiruddin et al. (2005) bahwa terkait dengan harga maka harga dari minyak nabati (seperti CPO dan minyak kedelai) terkait erat dengan minyak bumi. Senada juga dengan Pahan (2004) yang menyatakan bahwa dalam pengolahan minyak nabati maka sangat membutuhkan minyak bumi sebagai bahan bakarnya.

Kondisi harga $\mathrm{CPO}$ dalam negeri tidak seperti pada saat harga $\mathrm{CPO}$ naik dimana dengan intervensi pemerintah tetap stabil, namun saat $\mathrm{CPO}$ Internasional turun maka harga di dalam negeri juga turun. Harga CPO domestik yang pada Bulan Juni 2008 berkisar Rp 9544 per kilogram turun nilainya menjadi Rp 5364 per kilogram pada Bulan November 2008. Artinya harga CPO Indonesia dalam 6 bulan turun hingga setengahnya. Penurunan ini mengikuti trend yang terjadi di pasar internasional.

Pemerintah Indonesia sebenarnya telah melakukan intervensi dengan tujuan supaya produk CPO Indonesia tetap mampu bersaing di pasar Internasional. Adapun penghilangan hambatan ekspor itu diatur melalui Peraturan Menteri Keuangan No. 72/PMK.011/2008 yang isinya antara lain menurunkan pajak ekspor menjadi 2.5 persen dan No. 159/PMK.011/2008 yang isinya antara lain menghapuskan pajak ekspor hingga 0 persen. Namun ternyata harga CPO Indonesia tetap mengikuti penurunan harga Internasional. Dampak dari penurunan harga CPO di domestik tentu saja merugikan pihak produsen CPO. Pihak yang paling terkena imbasnya adalah petani kelapa sawit. 


\section{Harga Crude Palm Oil Indonesia}

Gambaran perkembangan posisi pergerakan harga $\mathrm{CPO}$ di Indonesia selama periode penelitian ditunjukkan pada Gambar 1.

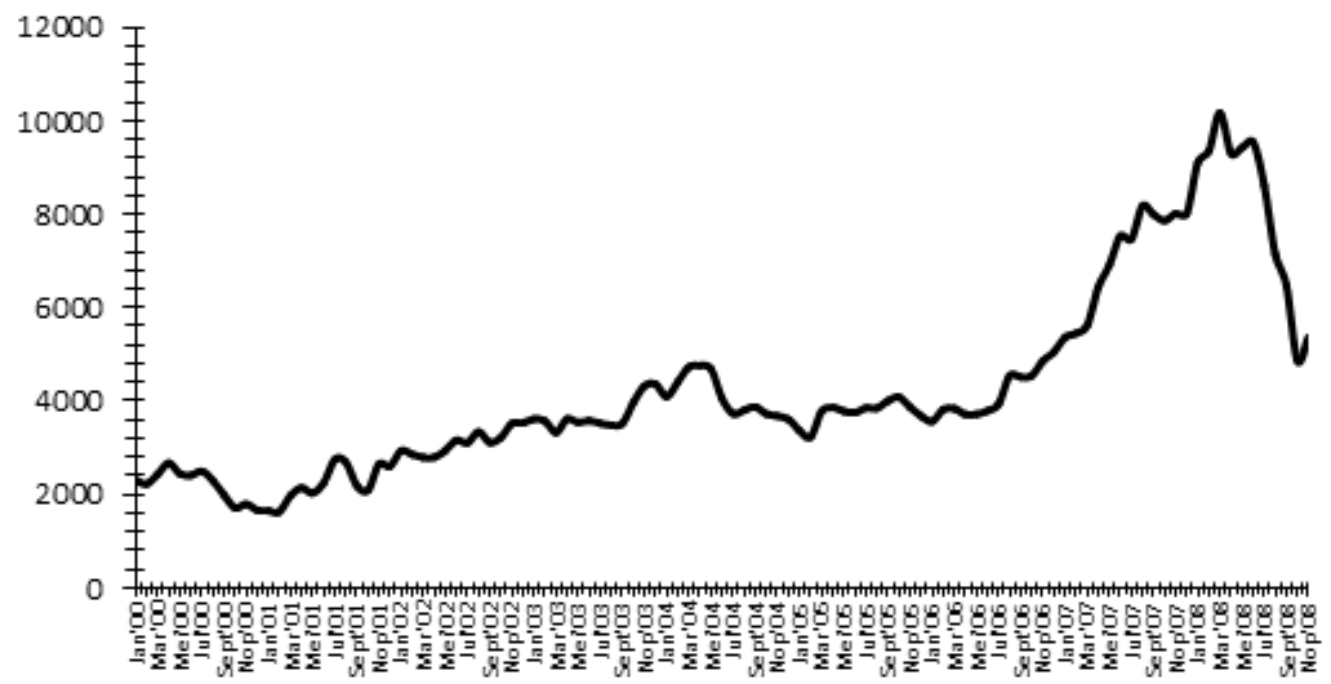

Sumber: Bappebti (diolah)

Gambar 1.

Pergerakan Harga Crude Palm Oil Indonesia Januari 2000-November 2008

Berdasarkan Gambar 1 maka dapat dilihat bahwa harga CPO di Indonesia cenderung berfluktuasi dari waktu ke waktu dimana dari Januari 2000 hingga Maret 2006 pergerakannya memiliki trend meningkat yang landai kemudian setelah Maret 2006 harga meningkat tajam dimana puncaknya terjadi pada Maret 2008 hal ini disebabkan beberapa faktor antara lain karena meningkatnya harga minyak mentah dunia sehingga seluruh komoditi yang diperdagangkan di dunia juga ikut naik dan juga karena peningkatan penggunaan CPO dimana akibat dari peningkatan harga minyak mentah dunia. Selain digunakan sebagai bahan pangan, CPO juga sebagai bahan bakar biodiesel namun setelah Maret 2008 kemudian harga CPO Indonesia terus menurun hal ini salah satunya disebabkan karena merupakan imbas dari krisis di Amerika yang kemudian merambat menjadi krisis global sehingga perekonomian dunia menjadi lesu.

Gambar 2 adalah grafik yang menunjukkan pergerakan pertumbuhan harga CPO Indonesia selama periode penelitian. Berdasarkan grafik tersebut dapat dilihat bahwa pertumbuhan harga CPO Indonesia memiliki volatilitas yang tinggi. Pada grafik juga dapat dilihat harga CPO Indonesia tidak stabil dimana harga sekarang lebih tinggi dibandingkan dengan harga bulan berikutnya hal ini dapat dilihat dari posisi grafik yang berada dibawah sumbu X. Variasi nilai pertumbuhan tertinggi adalah Rp.1097 yang terjadi pada Januari 2008 dan nilai pertumbuhan terendah adalah Oktober 2008 dengan nilai Rp 1618. 


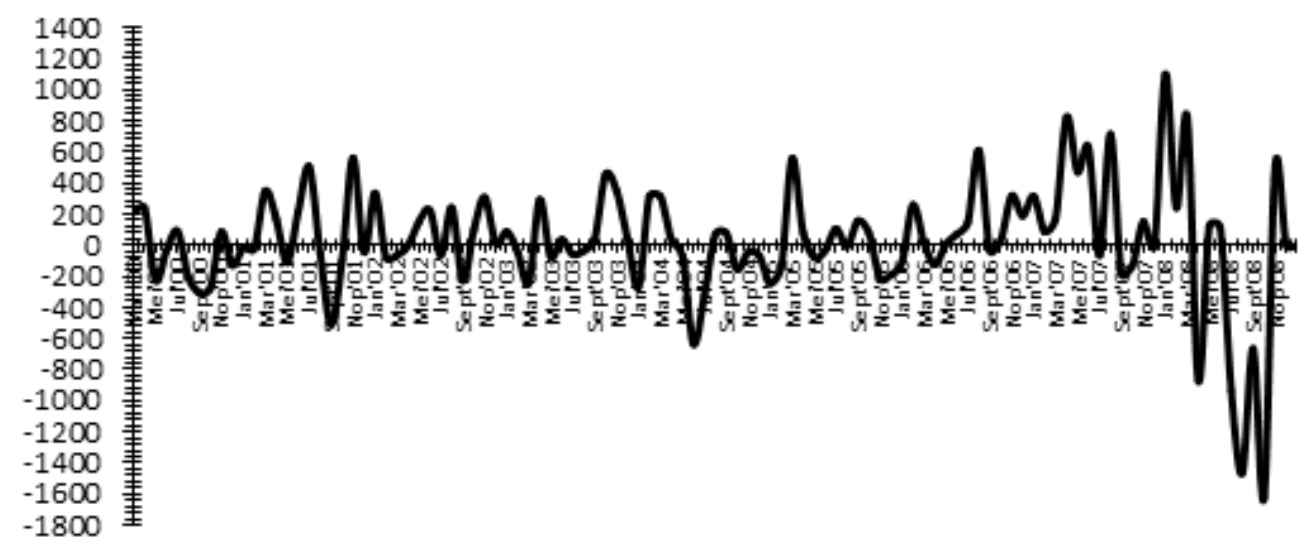

Sumber: Bappebti (diolah)

Gambar 2.

Pertumbuhan Harga Crude Palm Oil Indonesia Januari 2000-November 2008

Harga yang tidak stabil menyebabkan pelaku pasar CPO tidak bisa berpedoman pada harga yang terjadi sebelumnya karena harga selalu berubahubah dari waktu ke waktu. Selain itu volatilitasnya juga makin lama semakin besar dari waktu ke waktu artinya selisih harga sekarang dengan harga sebelumnya makin lama semakin jauh sehingga pelaku pasar tidak dapat memprediksikan harga kedepannya. Adapun rata-rata pertumbuhan harga CPO Indonesia adalah sebesar Rp28.77/bulan.

\section{IMPLIKASI KEBIJAKAN}

\section{Hubungan Harga Crude Palm Oil Indonesia dan Rotterdam}

Berdasarkan hasil penelitian yang dilakukan oleh Hafizah (2010) didapatkan hasil bahwa dalam jangka pendek yaitu periode satu bulan kedepan guncangan yang terjadi pada harga CPO Rotterdam akan langsung mempengaruhi pergerakan harga di Indonesia. Berbeda dengan respon Indonesia yang langsung bergerak saat Rotterdam diguncang ternyata Rotterdam tidak ikut bergerak waktu Indonesia dishock dimana nilai respon Rotterdam saat Indonesia bergerak adalah nol, dengan kata lain walaupun terjadi perubahan pada harga Indonesia namun Rotterdam tidak terpengaruh. Implikasi dari hal ini bahwa hubungan harga CPO antara pasar spot Indonesia dengan pasar forward Rotterdam adalah satu arah dimana Rotterdam mempengaruhi harga CPO Indonesia namun hal ini tidak berlaku sebaliknya karena Indonesia tidak dapat mempengaruhi harga di Rotterdam. Fenomena di atas mendukung teori yang menyatakan bahwa dalam proses penentuan harga, pasar spot merujuk pada pasar forward. Dalam hal ini adalah pasar spot Indonesia menjadikan pasar forward di Rotterdam sebagai referensinya dalam menentukan harga di Indonesia. 
Pasar forward sendiri terbentuk didasarkan pada keinginan pelaku pasar untuk mengurangi atau mengalihkan resiko harga yang mungkin dihadapi. Terutama pada komoditi pertanian karena ketergantungannya pada faktorfaktor luar seperti bencana alam, musim dan lainnya. Bentuk dari resiko itu antara lain terdapatnya deviasi harga yang tinggi antara satu periode dengan periode lainnya. Harga pada pasar forward di masa akan datang sudah disepakati pada saat perjanjian dibuat sehingga pelaku pasar tidak akan terpengaruh oleh kenaikan dan penurunan harga jual di pasar tunai. Berbeda dengan pembentukan harga di pasar spot, harga yang terbentuk berdasarkan pada kekuatan permintaan dan penawaran pada saat transaksi berlangsung sehingga volatilitas harga menjadi tinggi karena pelaku pasar tidak memiliki referensi harga namun hanya bisa melihat dari harga sebelumnya.

Temuan lainnya adalah hubungan antara Indonesia dan Malaysia adalah bersifat satu arah dimana harga CPO Malaysia mempengaruhi harga CPO di Indonesia namun tidak berlaku sebaliknya dimana harga CPO Indonesia tidak mempengaruhi harga CPO di Malaysia. Implikasi dari hasil ini adalah Indonesia dalam menentukan harga CPO domestiknya menjadikan harga CPO Malaysia sebagai referensinya. Dalam jangka pendek yaitu periode satu bulan kedepan guncangan yang terjadi pada harga CPO Rotterdam akan langsung mempengaruhi pergerakan harga di Malaysia.

Adapun respon Rotterdam pada saat terjadi guncangan pada Malaysia adalah nol. Artinya Rotterdam tidak merespon perubahan yang terjadi di Malaysia. Berdasarkan hal tersebut dapat dinyatakan bahwa hubungan yang terdapat antara harga CPO Malaysia dan harga CPO Rotterdam adalah bersifat satu arah dimana Rotterdam mempengaruhi Malaysia namun tidak berlaku kebalikannya. Harga CPO Malaysia tidak berpengaruh terhadap harga CPO Rotterdam.

Sama seperti yang terjadi pada pasar Indonesia, dimana pasar Malaysia adalah pasar yang melaksanakan transaksinya secara spot. Pasar Rotterdam yang merupakan pasar forward adalah merupakan pasar referensi untuk pasar spot di Malaysia dan Indonesia karena harga yang terbentuk di pasar forward sudah terbentuk terlebih dahulu sehingga dijadikan acuan untuk menentukan harga di pasar spot.

\section{Implikasi Kebijakan Pembentukan Harga Crude Palm Oil Indonesia}

Melihat hubungan yang terjadi melalui impulse response antarpasar spot Indonesia, Malaysia dan pasar forward Rotterdam didapatkan hasil bahwa yang menjadi pasar acuan adalah pasar forward Rotterdam dan yang menjadi pengikut pasar adalah pasar spot Indonesia dan Malaysia. Khususnya bagi Indonesia hal ini berarti bahwa sebagai pasar pengikut dalam pasar $\mathrm{CPO}$, posisi tawar Indonesia sebagai negara produsen masih kalah kuat dibandingkan dengan pembeli.

Salah satu cara untuk meningkatkan peranan Indonesia dalam penentuan harga CPO baik dunia atau domestik adalah dengan memperbaiki sistem 
pemasaran CPO Indonesia. Dengan membentuk bursa berjangka di Indonesia dan membangun future market khususnya bagi komoditi CPO maka volatilitas harga $\mathrm{CPO}$ yang terjadi selama ini akan dapat berkurang karena fungsi dari bursa berjangka adalah sebagai sarana untuk mengalihkan resiko dalam bentuk volatilitas harga yang tinggi. Resiko harga di sektor komoditi sangat besar karena beberapa faktor eksternal antara lain cuaca, kondisi ekonomi dan politik suatu negara, angkutan dan lain lain. Resiko harga tersebut akan lebih ditentukan sesuai dengan mekanisme pasar.

Harga yang terbentuk di bursa transparan karena pembeli dan penjual tidak bertemu dimana transaksi yang terjadi mencerminkan kekuatan pasokan dan permintaan yang sebenarnya hal ini adalah perbaikan dari sistem spot dimana pada saat yang sama penjual dan pembeli tidak memiliki informasi yang sama mengenai faktor-faktor yang mempengaruhi harga (asymmetry information). Tidak efisiennya perdagangan spot telah mengakibatkan standar yang tidak jelas, selain itu tidak diketahuinya kualitas barang yang dibeli mengakibatkan peningkatan biaya transaksi.

Semakin membaiknya arus informasi maka harga yang terjadi di pasar forward dapat dijadikan acuan oleh dunia usaha termasuk petani untuk melakukan transaksi di pasar fisik. Membaiknya arus informasi yang berhubungan dengan harga, produksi, konsumsi, volume perdagangan, dan juga perkiraan (ekspektasi) pasar, membuat pasar berjangka lebih transparan dan bersaing. Semakin banyak informasi tentang pasar diketahui orang, akan membuat mereka semakin mampu mengantisipasi pembentukan harga di pasar.

Adanya pasar berjangka juga dapat membantu terintegrasikannya pasarpasar lokal ke dalam pasar nasional atau bahkan internasional. Terintegrasikannya pasar nasional berarti harga di berbagai tingkat pemasaran yang berbeda akan bergerak mendekati pasar-pasar nasional dan internasional. Hal ini akan menjamin lebih realistisnya harga komoditi.

Fungsi pasar berjangka lainnya adalah sebagai hedging dimana didefinisikan sebagai pelindung prosesor terhadap naiknya bahan baku dan turunya nilai persediaan dan juga melindung pedagang dan eksportir dari kenaikan harga komoditi yang telah dikontrak untuk penyerahan kemudian namun belum dibeli. Jalan untuk membentuk suatu pasar berjangka di Indonesia telah dimulai oleh pemerintah Indonesia dengan mengeluarkan Undang-Undang No. 32 tahun 1997 yang berisi tentang aturan-aturan perdagangan berjangka komoditi dimana komoditi yang dapat dijadikan objek kontrak berjangka ditetapkan oleh keputusan presiden. Undang-undang ini merupakan landasan hukum pelaksanaan perdagangan berjangka di Indonesia (future trading) dimana definisi dari perdagangan berjangka adalah segala sesuatu yang berkaitan dengan jual beli komoditi yang pernyerahannya dilakukan kemudian sesuai dengan kontrak berjangka. Pasar yang dapat dijadikan tempat perdagangan berjangka telah ditentukan yaitu hanya di pasarpasar yang terorganisasi disebut juga sebagai bursa berjangka. Transaksi yang terjadi di bursa dilakukan oleh orang atau lembaga tertentu yaitu terdiri dari pialang berjangka dan perdagang berjangka, sedangkan bagi yang merupakan 
pengguna bursa namun bukan anggota bursa yang ingin menggunakan bursa harus melalui pialang berjangka. Adapun lembaga yang ditunjuk pemerintah untuk mengawasi perdagangan berjangka komoditi adalah Badan pengawas perdagangan berjangka komoditi (Bappebti) yang berada dibawah Departemen Perdagangan.

Selain itu dikeluarkan Peraturan Pemerintah No. 9 tahun 1999 dan Keputusan Presiden No. 12 tahun 1999 tentang penyelenggaraan perdagangan berjangka komoditi. Pada tahun 1999 terbentuk PT Bursa Berjangka yang merupakan Bursa Berjangka pertama di Indonesia dan telah mendapatkan izin usaha dari Bappebti. Pada tanggal 15 Desember 2000 Bursa Berjangka Jakarta beroperasi dimana sebagai tahap awal komoditi yang diperdagangkan adalah kopi robusta dan CPO. Keputusan Presiden No. 37 tahun 2000 tentang komoditi yang dapat dijadikan subjek kontrak berjangka yang terus diperbaharui setiap tahunnya.

Namun dalam prakteknya bursa berjangka komoditi ini masih memiliki beberapa kelemahan. Hambatan dalam melakukan lindung nilai antara lain adalah resiko basis hal ini terjadi karena perkembangan di pasar fisik tidak berkorelasi secara wajar dengan pasar berjangka akibatnya perencanaan yang ada tidak sesuai untuk diterapkan untuk menutupi resiko yang ada. Hambatan lainnya bagi hedger adalah terdapat beban biaya seperti pembayaran marjin dan biaya transaksi. Ketidaksesuaian (incompatible) antara kondisi fisik dan future adalah merupakan hambatan yang harus dihadapi oleh hedger. Hal ini disebabkan mutu dan jumlah produk yang dihedge tidak sama dengan mutu dan jumlah standar kontrak berjangka yang diperdagangkan.

Adapun kelemahan bursa berjangka antara lain agar efisien jumlah komoditi yang ditawarkan haruslah besar, atau biaya pemasaran tidak akan tertutupi. Hal ini tentu saja menjadi masalah bila diterapkan di Indonesia karena tipe petani produsen yang banyak terdapat di negara ini adalah petani produsen yang memiliki jumlah komoditi yang terbatas dan kepemilikan lahan yang tersebar sehingga apabila mereka ikut bertransaksi dalam pasar berjangka komoditi akan memberikan biaya yang besar sekali. Selain itu dengan seluruh syarat-syarat yang ditetapkan maka petani Indonesia yang kebanyakan tidak memiliki pengetahuan yang cukup tidak akan bisa memanfaatkan keberadaan dari bursa berjangka ini.

Selain dengan membangun suatu pasar berjangka di Indonesia cara lain untuk meningkatkan peranan Indonesia dalam perdagangan $\mathrm{CPO}$ adalah dengan dengan meningkatkan nilai tambah dari CPO dengan mengembangkan produk-produk hilir CPO. Apabila CPO sudah diolah menjadi produk turunan yang memberikan manfaat lebih daripada yang ada selama ini, maka akan meningkatkan permintaan akan CPO. Indonesia juga dapat memanfaatkan produk-produk turunan $\mathrm{CPO}$ yang diproduksi untuk memenuhi permintaan di dalam negeri. Bila permintaan dalam negeri semakin tinggi dan sudah dapat dipenuhi oleh industri hilir di Indonesia maka CPO Indonesia tidak akan tergantung dengan pihak lain dalam menentukan harga. 


\section{SIMPULAN DAN SARAN}

\section{Simpulan}

1. Pasar Rotterdam sangat mempengaruhi pembentukan harga $\mathrm{CPO}$ di Indonesia. Penurunan harga CPO pada Pasar Rotterdam akan langsung menyebabkan harga CPO Indonesia akan turun.

2. Untuk memperbaiki posisi tawar Indonesia maka salah satu strategi yang dapat dilakukan adalah dengan mengefektifkan bursa berjangka di Indonesia dan mengembangkan industri hilir dari minyak kelapa sawit.

\section{Saran}

Adapun saran yang dapat disampaikan dari penelitian ini adalah :

1. Perlu adanya konsolidasi produksi agar lebih mengoptimalkan bursa berjangka dan meminimalkan biaya di bursa. Selain itu konsolidasi produksi juga penting untuk menjamin likuiditas produk CPO untuk diperdagangkan di lantai bursa.

2. Selain mengefektifkan bursa berjangka, permintaan dalam negeri untuk keperluan industri pengolahan juga harus ditingkatkan. Untuk keperluan tersebut dibutuhkan kebijakan pemerintah yang dapat mendorong pengembangan industri pengolahan minyak kelapa sawit.

\section{DAFTAR PUSTAKA}

Adang, A. dan P.U. Hadi. 2002. Analisis Dinamika Ekspor dan Keunggulan Komparatif Minyak Kelapa Sawit di Indonesia. Pusat Penelitian Sosial Ekonomi Pertanian, Badan Penelitian dan Pengembangan Pertanian Bogor, Bogor.

Capricorn Indonesia Consult (CIC) Inc. 2004. Studi Tentang Industri dan Perkebunan Kelapa Sawit Indonesia. Capricon Indonesia Consult, Jakarta.

Hafizah, D. 2010. Aplikasi Vector Autoregression (VAR) dalam Integrasi Pasar CPO di Indonesia, Malaysia dan Belanda. Prosiding Seminar Nasional dan Rapat Tahunan Dekan. Bidang Ilmu Ilmu Pertanian Perguruan Tinggi Wilayah Barat. Universitas Bengkulu. Bengkulu.

Nazir, 1999. Metode Penelitian. Ghalia Indonesia. Jakarta.

Pahan, I. 2008. Panduan Lengkap Kelapa Sawit: Manajemen Agribisnis dari Hulu Hingga Hilir. Penebar Swadaya, Jakarta.

Rifin, A. 2009. Analisis Pemasaran Minyak Kelapa Sawit di Indonesia. Dalam Bunga Rampai Agribisnis: Seri Pemasaran. Departemen Agribisnis, Fakultas Ekonomi dan Manajemen. Institut Pertanian Bogor Press, Bogor.

Sugema, I., M.F. Hasan, Aviliani, U. Hidayat dan Sugiyono. 2007. Strategi Pengembangan Kelapa sawit. Institute of Development and Finance, Jakarta.

Dian Hafizah. Kajian Kebijakan Pemerintah dalam Perdagangan CPO... | 170 